\title{
SOCCER CLEATS WITH BLADE-SHAPED STUDS AND MECHANICAL OVERLOAD IN SOCCER: A SYSTEMATIC REVIEW
}

\author{
CHUTEIRA COM TRAVAS EM FORMA DE LÂMINA E SOBRECARGA MECÂNICA NO FUTEBOL: \\ UMAREVISÃOSISTEMÁTICA
}
BOTINES DE FÚTBOL CON TOPEROLES EN FORMA DE LÁMINA Y SOBRECARGA MECÁNICA EN EL FÚTBOL: REVISIÓN SISTEMÁTICA

\begin{abstract}
Systematic Review Article ARTIGo de REVISÃo SISTEMÁtICA Artículo de REVISIÓN SISTEMÁtICA
\end{abstract}

Carlos Alberto Cardoso Filho'
(Physical Education Professional)
João Gustavo Claudino'
(Physical Education Professional)
Wilson Pereira Lima'
(Physical Education Professional)
Alberto Carlos Amadio'
(Physical Education Professional)
Júlio Cerca Serrão'
(Physical Education Professional)

1. Universidade de São Paulo, Escola de Educação Física e Esporte, Biomechanics Laboratory, São Paulo, SP, Brazil.

\section{Correspondence:}

Carlos Alberto Cardoso Filho. Av. Professor Mello Moraes, 65, Butantã, São Paulo, SP, Brazil. 05508-030.carlos.filho@usp.br

\begin{abstract}
Soccer cleats with blade-shaped studs promote greater traction on the pitch and can be beneficial for soccer performance. On the other hand, movements with rapid changes of direction, associated with the high traction of soccer cleats, can increase overload and risk of injuries. Given the lack of consensus on the effects of these cleats on mechanical overload during specific soccer movements, the aim of this systematic review was to determine the effects of wearing cleats with bladed studs on mechanical overload in soccer. A search was conducted in the PubMed, Scopus, and Web of Science electronic databases between October and November 2017. Non-original articles were excluded, as were those not related to soccer or cleats, and those not written in English. Eight articles were included that tested the effects of bladed studs on overload and that used biomechanical tests. The tasks evaluated were: running in a straight line or with changes of direction, and landing of jumps. The resulting joint torque, soil reaction force, electromyography, and plantar pressure were measured. There was no influence of bladed shaped studs on joint torque or on ground reaction force. There was an increase in plantar pressure on the lateral part of the foot in bladed studs compared to Society cleats and running shoes. When compared with round studs, the results were inconclusive for plantar pressure. Round studs, caused greater electromyographic activity in the quadriceps muscles than bladed studs. It was concluded that wearing bladed-stud cleats does not result in greater mechanical overload during running or landing of jumps. Evidence Level I, Systematic Review.
\end{abstract}

Keywords: Soccer; Wounds and injuries; Mechanics.

\section{RESUMO}

As chuteiras com travas em forma de lâmina promovem uma alta tração no gramado, podendo ser benéficas para o desempenho no futebol. Por outro lado, movimentos com rápidas mudanças de direção associados com tração alta das chuteiras podem aumentar a sobrecarga e as chances de lesão. Diante da falta de consenso sobre os efeitos dessas chuteiras na sobrecarga mecânica durante movimentos específicos do futebol, o objetivo desta revisão sistemática foi determinar os efeitos da utilização das chuteiras com travas em forma de lâmina na sobrecarga mecânica no futebol. A pesquisa foi realizada nos bancos de dados eletrônicos PubMed, Scopus e Web of Science entre outubro e novembro de 2017. Os artigos excluídos foram os não originais, não relacionados com o futebol ou às chuteiras e cujo idioma não fosse o inglês. Foram incluídos oito artigos que testaram os efeitos das travas em forma de lâmina na sobrecarga e que utilizaram testes biomecânicos. As tarefas avaliadas foram: corrida em linha reta ou com mudança de direção, e aterrissagem de saltos. Foram medidos o torque articular resultante, a força de reação do solo, a eletromiografia e a pressão plantar. Não houve influência das travas em forma de lâmina nos torques articulares e na força de reação do solo. Observou-se um aumento na pressão plantar na parte lateral do pé nas travas em forma de lâmina na comparação com as chuteiras Society e com calçados de corrida. Na comparação com as travas redondas, os resultados foram inconclusivos para a pressão plantar. As travas redondas provocaram maior atividade eletromiográfica nos músculos do quadríceps do que as travas em forma de lâmina. Concluiu-se que o uso da chuteira com travas em forma de lâmina não resulta em maior sobrecarga mecânica durante corridas ou aterrissagem de saltos. Nível de evidência I, Revisão Sistemática.

Descritores: Futebol; Ferimentos e lesões; Mecânica.

\section{RESUMEN}

Los zapatos de fútbol con toperoles en forma de lámina promueven alta tracción en el césped, pudiendo ser beneficiosas para el desempeño en el fútbol. Por otro lado, los movimientos con rápidos cambios de dirección asociados con tracción alta de los zapatos de fútbol pueden aumentar la sobrecarga y las posibilidades de lesión. Ante la falta de consenso sobre los efectos de estos zapatos durante movimientos específicos del fútbol, el objetivo de esta revisión sistemática fue determinar los efectos de la utilización de los zapatos de fútbol con toperoles en forma de lámina en la sobrecarga mecánica en el fútbol. La búsqueda fue realizada en las bases de datos electrónicos de PubMed, Scopus y Web of Science entre octubrey noviembre de 2017. Los artículos excluidos fueron los no originales, no relacionados con 
el fútbol o los zapatos de fútbol y cuyo idioma no fuera el inglés. Se incluyeron ocho artículos que probaron los efectos de los toperoles en forma de lámina en la sobrecarga y que utilizaron pruebas biomecánicas. Las tareas evaluadas fueron: carrera en línea recta o con cambio de dirección y aterrizaje de saltos. Se midieron el torque articular resultante, la fuerza de reacción del suelo, la electromiografía y la presión plantar. No hubo influencia de los toperoles en forma de lámina en los torques articulares y en la fuerza de reacción del suelo. Se observó un aumento en la presión plantar en la parte lateral del pie para los toperoles en forma de lámina en la comparación con los zapatos de fútbol Society los calzados de carrera. En comparación con los toperoles redondos, los resultados fueron inconclusos para la presión plantar. Los toperoles redondos provocaron mayor actividad electromiográfica de los músculos cuádriceps que los toperoles en forma de lámina. Se concluyó que el uso del zapa to de fútbol con toperoles en forma de lámina no resulta en mayor sobrecarga mecánica durante carreras o aterrizaje de saltos. Nivel de Evidencia l, Revisión Sistemática.

Descriptores: Fútbol; Heridas y lesiones; Mecánica.

\section{INTRODUCTION}

Soccer is one of the most practiced sports in the world, ${ }^{1}$ with more than 270 million practitioners. ${ }^{2}$ Over the years, there has been a significant increase in the distances traveled by the players during soccer matches, exceeding $11 \mathrm{~km}$ currently. In order to help the athletes move better, the soccer boots, a mandatory gear in soccer ${ }_{1}^{4}$ have been adjusted, ${ }^{5}$ becoming lighter for better pull force on the field. Good traction of soccer boot studs on the lawn is critical to good performance in specific game movements such as acceleration and deceleration runs, change of direction and kicking performance. ${ }^{6,7}$ Handling the traction of boot studs is done by increasing or decreasing the penetration of studs on the lawn or by changing the contact area of the boot sole with the playing surface. ${ }^{8}$ This can also be achieved by changing the geometry of studs to a round, conical, triangular or blade shape. ${ }^{9}$

Blade-shaped studs, also known as shark-tooth studs, are designed to promote better traction, reduced slippage and greater kicking stability. ${ }^{10,11}$ These studs promote higher friction torque ${ }^{12}$ and improves performance, especially in runs with change of direction, ${ }^{6,13}$ compared with round-shaped studs. On the other hand, runs with fast changes of direction associated with high boot traction can increase the mechanical overload, especially to the knee joint, causing a potential increase in the risk of anterior cruciate ligament $(\mathrm{ACL})$ injuries. ${ }^{12,14-17}$ Besides that, the greater traction promoted by the penetration of the studs in the lawn can promote greater peaks of pressure on the sole of the feet, ${ }_{1}^{18}$ as well as greater incidence of metatarsal stress injuries. ${ }^{19}$

In view of the high incidence of soccer injuries, ${ }^{20}$ different studies have proposed to investigate the relationship between the studs and the injuries. 9,11,21 Although the causes of injuries are multifactorial in nature, they result from the force generated by the sum of loads that exceed the limit supported by the biological tissue.22 Thus, a better understanding of the overload resulting from the use of blade-shaped studs in soccer contributes to breakthroughs in this area of knowledge. This study aims to execute a systematic review to determine the influence of soccer boots with blade-shaped studs on mechanical overload in soccer movements.

\section{METHODS}

The PRISMA (Preferred Reporting Items for Systematic Reviews and Meta-Analysis) recommendations were followed in this systematic review. ${ }^{23}$ The following databases were searched: PubMed, Web of Science and Scopus, between October 11 and November 26, 2017. The following terms were used in the search: soccer, football, shoes, boots, biomechanical, biomechanics, kinetics, kinematics, pressure, electromyography, mechanical, injury, pain, injuries. The search strategy for all databases was the following: ("soccer" or "football") and ("shoes" or "boots" or "bladed") and ("biomechanical" or"biomechanics" or "kinetics" or"kinematics" or"pressure" or "electromyography" or "mechanical" and "injury" or "pain" or "injuries").

A single reviewer selected the studies based on the titles. Subsequently, the duplicates were removed and the abstracts were read to identify those who met the inclusion criteria: articles written in English, original studies, studies related to soccer, studies related to the influence of boot studs. After exclusion of articles that did not meet the inclusion criteria, the remaining articles were selected to be fully read and those that did not investigate overload due to the use of blade-shaped studs or used only mechanical tests were excluded. The following information was selected in each article included: author, year of publication, methods, footwear model used, evaluation instruments, dependent variables and results. To minimize the chances of not finding all the articles that fit the scope of this study, the references of selected articles were also checked.

Quality evaluation of each study was done by two reviewers using the scale developed by Downs and Black. ${ }^{24}$ An adaptation of the original scale used in previous studies related to biomechanical factors and sports injuries was adopted, 25,26 in which items 1,2,3, 4, 6 and 7 were selected on what was reported in studies 11 and 12 on external validity, 16, 18, 20 and 25 on internal validity. Any inconsistencies between reviewers were resolved by consensus.

\section{RESULTS}

In the three related databases, 190 articles were found. One article was included by reading references from other studies. ${ }^{27} \mathrm{After}$ the duplicates were removed, 107 articles remained. After reading the abstracts, articles were excluded because they were not English $(n=5)$, did not focus on soccer $(n=33)$, were not related to soccer boots $(n=12)$, or were literature reviews and meta-analyses $(n=16)$, book chapter $(n=2)$, abstracts from conferences $(n=7)$. Of the articles that were selected for full reading $(n=28)$, those that did not compare the boots with blade-shaped studs with other footwear $(n=19)$, or those that used only mechanical tests $(n=1)$ were excluded. Eight studies ${ }^{27-34}$ were included in the systematic review. (Figure 1)

\section{Characteristics of the studies}

The characteristics of the studies selected in this review are presented in Table 1.Six studies evaluated the influence of blade-shaped boot studs on mechanical overload during straight-line runs or runs with change of direction, ${ }_{1}^{27-30,32,34}$ and two studies focused on mechanical overload during jump landing. ${ }^{31,33}$ The main outcomes were related to plantar pressure, ${ }^{28,32,33}$ angles and joint torques, ${ }^{27,29-31}$ soil reaction force, ${ }^{29,34}$ and electromyographic activity. ${ }^{29}$

A total of 175 volunteers participated in the eight studies selected, of which 131 were males and 44 were females. Three studies evaluated 


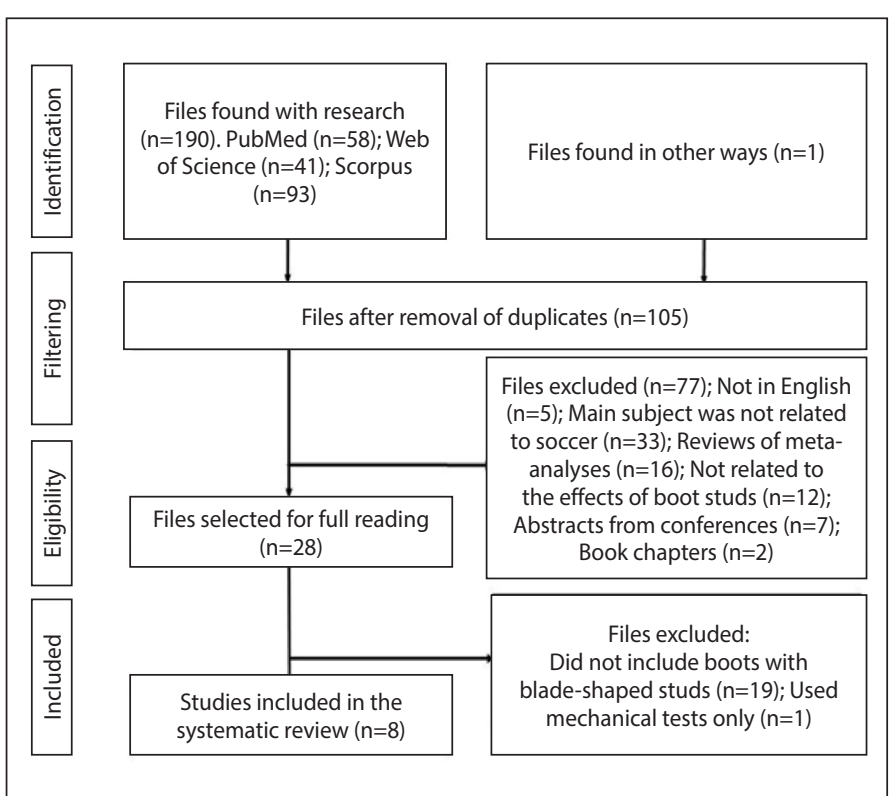

Figure 1. Flowchart of selection of scientific articles.

men and women ${ }^{28,31,33}$ and the others evaluated only men. ${ }^{27,29,30,32,34}$ Sixty-one volunteers were evaluated for knee joint torque, ${ }^{27,29-31}$ forty volunteers on ankle joint torque $\mathrm{e}^{27,31}$ and 28 volunteers on hip torque. ${ }^{31}$ Ninety-two volunteers had their plantar pressure assessed ${ }^{28,32,33}$, fifty-six people participated in the ground reaction force evaluation, 29,31,34 and six people participated in electromyography. ${ }^{29}$ Comparisons of boots with blade-shaped studs with boots with round-shaped studs $27-30,32,34$, with turf shoes $28,31,33,34$ and with running shoes..$^{27,31,33}$ The analysis of methodological quality of the studies is presented in Table 2.

\section{Mechanical overload in runs}

In both straight-line runs and runs with change of direction, compared with round-stud boots, boots with blade-shaped studs did not result in greater flexor-extensor torque, 27,29,30 adductor-abductor torque 27,30 or internal-external rotator torque ${ }^{27,30}$, knee joint torque $27,29,30$ and ankle torque. ${ }^{27}$ Also, there was no difference in influence on the ground reaction force on vertical axes, ${ }^{29,34}$ antero-posterior axes ${ }^{29}$ and lateral medial axes $^{29}$ between the shoes. The use of boots with round-shaped studs resulted in greater electromyographic signal in the quadriceps muscles compared with blade-shaped studs. One study ${ }^{32}$ found greater plantar pressure in the lateral region of the forefoot and in the lateral metatarsals, caused by boots with blade-shaped studs compared with boots with round-shaped studs. On the other hand, Queen et al. ${ }^{28}$ observed this pressure increase from the use of blade-shaped studs, only in comparison with turf shoes, without any difference in the pressure distribution in comparison with round-shaped studs.

\section{Mechanical overload on landing}

Both studies related to landing made comparisons between the blade-shaped studs with turf shoes and running shoes. ${ }^{31,33}$ In horizontal jumps, there was no influence of blade-shaped studs on GRF on the vertical axis or on knee and hip flexion-extension torque. On the other hand, blade-shaped studs caused greater dorsiflexion compared with turf shoes, and increased flexion-extension torque at the ankle compared to running shoes. 31 In the vertical jump, the boots did not influence the flexor-extensor torque of the knee, ankle and hip. However, there was greater dorsiflexion in men ${ }^{31}$, lower peak of knee flexion in women ${ }^{31}$ and greater pressure overload in the midfoot from the use of blade-shaped studs ${ }^{33}$ compared with running shoes and turf shoes.

\section{DISCUSSION}

This review aimed to investigate the effects of boots with blade-shaped studs on mechanical overload in specific soccer movements. The findings of the eight studies included in this review show that during runs with and without change of direction and in landings, boots with blade-shaped studs did not cause any significantly negative influence on the biomechanical parameters related to overload.

Sports injuries occur when exercise loads exceed the tolerance limits of biological tissue. ${ }^{22,35}$ If a sports shoe does not meet the athlete's specific needs, there may be changes to movement patterns that overload certain structures favoring the onset of pain and injury. ${ }^{36}$ One of the greatest concerns in soccer is the effect of boot stud traction and the overload directed to the ACL which, if injured, demands a long recovery period ${ }^{15,20,37}$ and high medical-hospital expenditures, reaching annual amounts of US\$ 646 million. ${ }^{38}$ The specialized literature reports that, regardless of the type of footwear, the combination of factors such as smaller knee flexion amplitude, adduction with internal rotation of the same joint, dynamic valgus, ${ }^{39}$ and greater ground reaction force ${ }^{40}$ during typical soccer movements, results in major ACL overload, which can cause contactless injury. ${ }^{39}$

The act of quantifying the exact internal loads of biological tissues during sports movements can be quite invasive and complex, ${ }_{1}^{27}$ so inverse dynamics is used to calculate the torque resulting from each joint and these are good indicators of mechanical overload. ${ }^{38}$ The findings from this study point out that during the straight-line runs and runs with change of direction, there were no significant differences in flexion-extension, adduction-abduction and internal-external rotation torque at the knee joint $27,29,30$ and ankle joint ${ }^{27}$ between boots with blade-shaped studs and boots with round-shaped studs. Although the studies did not measure internal overload directly, ${ }^{27,29-31}$ so far, biomechanical evidence by means of inverse dynamics do not corroborate the assumption that boots with blade-shaped studs would favor greater appearance of injuries, such as ACL tears, compared with round studs. $12,14,27,41$

Besides, the findings indicate that during landing, the use of blade-shaped studs does not significantly change mechanical overload in men. ${ }^{31}$ On the other hand, there is greater interference in the mechanics of landing in women, ${ }^{31}$ so further studies with this specific population are still necessary for definitive conclusions.

Only one study ${ }^{29}$ evaluated the electromyographic activity of the thigh muscles, and showed lower electrical activity of the quadriceps muscles caused by blade-shaped studs compared with round-shaped studs during runs with change of direction. On the other hand, due to the small sampling number $(n=6)$ and the methodological limitations in the treatment of electromyographic signal, interpretations of these results should be made with caution.

Stress fractures in the fifth metatarsal region have a low incidence in soccer, but are considered of concern due to the high rates of relapse and the time required for recovery. ${ }^{42}$ Although the relationship between the boots and the incidence of stress fractures is inconclusive ${ }_{1}^{43}$ it is suggested that foot pressure overloads may be a risk factor for stress injuries, ${ }^{19,44,45}$ mainly in the fifth metatarsal region. ${ }^{42,43}$ While Queen et al. ${ }^{28}$ did not find any differences in pressure distribution between boots with round-shaped studs and boots with blade-shaped studs, Bentley et al. ${ }^{32}$ found higher pressure peaks at the lateral border of the foot caused by boots with blade-shaped studs. Although both studies have selected boots of similar material, in which the only differentiating characteristic was the stud geometry, there is insufficient evidence to contraindicate boots with blade-shaped studs over boots with round-shaped studs for a lower risk of injury. 28,33 
Table 1. Characteristics of the studies selected in the review.

\begin{tabular}{|c|c|c|c|c|}
\hline Author & Methods & Instruments and shoes & Dependent Variable & Results of dependent variables \\
\hline \multirow[b]{2}{*}{$\begin{array}{l}\text { Bentley } \\
\text { et al. }{ }^{32}\end{array}$} & \multirow[b]{2}{*}{ Task: Straight-line run } & Pressure insoles & \multirow[b]{2}{*}{$\begin{array}{l}\text { Pressure peaks; Integral } \\
\text { of pressure by time. }\end{array}$} & \multirow{2}{*}{$\begin{array}{l}\text { The boots with round-shaped studs presented } \\
\text { higher pressure peaks than the boots with blade- } \\
\text { shaped studs in areas with normal stepping } \\
\text { pattern. On the other hand, the boots with blade- } \\
\text { shaped studs presented greater pressure overloads } \\
\text { on the side of the midfoot and forefoot. }\end{array}$} \\
\hline & & $\begin{array}{l}\text { One boot with blade-shaped } \\
\text { studs and one boot with } \\
\text { round-shaped studs }\end{array}$ & & \\
\hline \multirow[b]{2}{*}{ Butler et al..$^{31}$} & \multirow[b]{2}{*}{$\begin{array}{l}\text { Task: Jumping and } \\
\text { head a ball }\end{array}$} & $\begin{array}{l}\text { Force platform; kinematic } \\
\text { evaluation system }\end{array}$ & \multirow{2}{*}{$\begin{array}{l}\text { The variables were analyzed } \\
\text { during landing conditions. } \\
\text { Ground reaction force (vertical } \\
\text { axis); peak of knee flexion; } \\
\text { flexor-extensor knee torque; } \\
\text { peak flexor-extensor hip torque; } \\
\text { flexor-extensor ankle torque; } \\
\text { peak ankle dorsiflexion. }\end{array}$} & \multirow{2}{*}{$\begin{array}{l}\text { Men: Greater dorsiflexion using boots with blade-shaped } \\
\text { studs compared with other footwear. Women: smaller } \\
\text { knee flexion with boots with blade-shaped studs. } \\
\text { No significant influence of blade-shaped stud on } \\
\text { knee and hip resulting joint torques. The bladed- } \\
\text { shaped studs increased flexion-extension torque } \\
\text { at the ankle compared to running shoes }\end{array}$} \\
\hline & & $\begin{array}{l}\text { Running shoes, artificial } \\
\text { lawn shoes, boots with } \\
\text { blade-shaped studs }\end{array}$ & & \\
\hline \multirow[b]{2}{*}{$\begin{array}{l}\text { DeBiaso } \\
\text { et al. }\end{array}$} & \multirow[b]{2}{*}{$\begin{array}{l}\text { Task: Jumping and } \\
\text { heading a ball. }\end{array}$} & Pressure insoles & \multirow[b]{2}{*}{$\begin{array}{l}\text { Maximum force, contact area, } \\
\text { peak pressure, contact time } \\
\text { and force-time integral. }\end{array}$} & \multirow[b]{2}{*}{$\begin{array}{l}\text { The boots presented greater maximum force compared } \\
\text { with running shoes. Boots with blade-shaped studs } \\
\text { presented a smaller area of contact than the other shoes. } \\
\text { There were also higher force-time integral values for } \\
\text { the boot with blade-shaped studs compared with turf } \\
\text { shoes, especially in the lateral region of the forefoot. }\end{array}$} \\
\hline & & $\begin{array}{l}\text { Running shoes, artificial } \\
\text { lawn shoes, boots with } \\
\text { blade-shaped studs }\end{array}$ & & \\
\hline \multirow{2}{*}{$\begin{array}{l}\text { Gehring } \\
\text { et al. }{ }^{29}\end{array}$} & \multirow{2}{*}{$\begin{array}{c}\text { Task: running with } \\
\text { change of direction }\left(180^{\circ}\right)\end{array}$} & $\begin{array}{l}\text { Force platform; } \\
\text { Electromyograph; kinematic } \\
\text { evaluation system }\end{array}$ & \multirow{2}{*}{$\begin{array}{l}\text { Ground reaction force } \\
\text { (vertical, antero-posterior } \\
\text { and mid-lateral); flexor- } \\
\text { extensor knee torque; Peak } \\
\text { electromyographic activity } \\
\text { (quadriceps and hamstrings); }\end{array}$} & \multirow{2}{*}{$\begin{array}{l}\text { No significant differences were found for the three } \\
\text { ground reaction force axes and for the flexor-extensor } \\
\text { knee torque as a function of the boot worn. Round- } \\
\text { shaped studs caused greater electromyographic } \\
\text { activity of the quadriceps than blade-shaped studs. }\end{array}$} \\
\hline & & $\begin{array}{l}\text { Boots with blade-shaped studs; } \\
\text { boots with round-shaped studs. }\end{array}$ & & \\
\hline \multirow[b]{2}{*}{ Kaila } & \multirow{2}{*}{$\begin{array}{c}\text { Task: Straight-line run and } \\
\text { runs with fast changes of } \\
\text { direction }\left(30^{\circ} \text { and } 60^{\circ}\right)\end{array}$} & $\begin{array}{l}\text { Force platform; kinematic } \\
\text { evaluation system }\end{array}$ & \multirow{2}{*}{$\begin{array}{l}\text { Knee flexion angle; Flexor- } \\
\text { extensor knee torque; Adductor- } \\
\text { abductor knee torque; Internal- } \\
\text { external knee rotator torque. }\end{array}$} & \multirow[b]{2}{*}{$\begin{array}{l}\text { No significant differences were found for each of the } \\
\text { variables evaluated according to the type of boot worn. }\end{array}$} \\
\hline & & $\begin{array}{l}\text { Two models of boots } \\
\text { with blade-shaped studs; } \\
2 \text { boot models with } \\
\text { round-shaped studs }\end{array}$ & & \\
\hline \multirow[b]{2}{*}{$\begin{array}{l}\text { McGhie and } \\
\text { Ettema }^{34}\end{array}$} & \multirow{2}{*}{$\begin{array}{l}\text { Task: Run with change of } \\
\text { direction }\left(90^{\circ}\right) \text { and run } \\
\text { with fast deceleration }\end{array}$} & Force platform, photocells & \multirow{2}{*}{$\begin{array}{l}\text { Peak impact on ground } \\
\text { reaction force, ground contact } \\
\text { time, linear velocity. }\end{array}$} & \multirow{2}{*}{$\begin{array}{l}\text { Run with change of direction: Smaller linear velocity } \\
\text { on the blade-shaped studs, higher impact peak } \\
\text { with boots with round-shaped studs, with no } \\
\text { differences in the contact time between the boots. } \\
\text { Run with deceleration: No differences in linear } \\
\text { velocity and impact peak between the boots, } \\
\text { greater contact time on turf shoes, followed by } \\
\text { round-shaped studs and blade-shaped studs. }\end{array}$} \\
\hline & & $\begin{array}{c}\text { Boots for artificial lawn, boots } \\
\text { with round-shaped studs, boots } \\
\text { with blade-shaped studs. }\end{array}$ & & \\
\hline \multirow[b]{2}{*}{$\begin{array}{l}\text { Queen } \\
\text { et al. }{ }^{28}\end{array}$} & \multirow[b]{2}{*}{$\begin{array}{l}\text { Task: Straight-line run } \\
\text { and run with change } \\
\text { of direction }\left(180^{\circ}\right)\end{array}$} & Pressure insoles & \multirow[b]{2}{*}{$\begin{array}{l}\text { Contact time; contact area; } \\
\text { Pressure peak; Force-time } \\
\text { integral of the forefoot regions; } \\
\text { maximum vertical force. }\end{array}$} & \multirow{2}{*}{$\begin{array}{l}\text { Higher force-time integral value on the } \\
\text { side of the forefoot for boots with blade- } \\
\text { shaped studs compared with turf shoes. }\end{array}$} \\
\hline & & $\begin{array}{l}\text { Boots with blade-shaped } \\
\text { studs; boots with high round- } \\
\text { shaped studs, boots with } \\
\text { low round-shaped studs and } \\
\text { boots for artificial lawns. }\end{array}$ & & \\
\hline \multirow[b]{2}{*}{$\begin{array}{l}\text { Stefanyshyn } \\
\text { et al. }{ }^{27}\end{array}$} & \multirow[b]{2}{*}{$\begin{array}{l}\text { Task: Run with change of } \\
\text { direction }\left(45^{\circ}\right) \text { and }\left(180^{\circ}\right)\end{array}$} & $\begin{array}{l}\text { Force platform; kinematic } \\
\text { evaluation system }\end{array}$ & \multirow{2}{*}{$\begin{array}{l}\text { Ankle: flexor-extensor torque, } \\
\text { internal-external rotator torque } \\
\text { and adductor-abductor torque. } \\
\text { Knee: flexor-extensor torque, } \\
\text { adductor-abductor torque, } \\
\text { internal-external rotator torque }\end{array}$} & \multirow{2}{*}{$\begin{array}{l}\text { Change of direction }\left(45^{\circ}\right) \text { : There was no influence of } \\
\text { the footwear on each of the resulting torques in both } \\
\text { the knee and the ankle. Change of direction }\left(180^{\circ}\right) \text { : } \\
\text { greater internal-external knee and ankle rotator torque } \\
\text { for the three boots compared with running shoes. No } \\
\text { differences between the boots for the evaluated torques. }\end{array}$} \\
\hline & & $\begin{array}{l}\text { Running shoes, boots with } 12 \\
\text { round-shaped studs, boots } \\
\text { with } 6 \text { round-shaped studs and } \\
\text { boots with blade-shaped studs. }\end{array}$ & & \\
\hline
\end{tabular}

It was also found that boots with blade-shaped studs present greater pressure overload on the lateral border of the feet and on the forefoot compared with turf shoes ${ }^{28,33}$ or running shoes. ${ }^{33}$ However, both running shoes and turf shoes are not normally used in professional soccer matches, so the differences found in the pressure overload between these and boots with blade-shaped studs should be interpreted with caution, and may serve to guide the choice of these alternative footwear in training situations during the stages of recovery of stress injury on the feet bones, ${ }^{33}$ especially in the fifth metatarsal region.

Although there is no direct relationship between the incidence of injuries and the magnitude of the $\mathrm{GRF}_{1}^{25,46}$ higher values in the rate of force development in the vertical axis of GRF are associated with stress fractures, especially in the tibia. ${ }^{25,47}$ However, none of the selected studies looked at this particular variable. Only the force peaks were evaluated, and it was found that boots with blade-shaped studs did not influence the vertical axis of GRF in straight-line runs ${ }^{34}$ and landing. ${ }^{31}$ In runs with change of direction, there was no significant influence of blade-shaped studs on the three GRF axes, ${ }^{29}$ and one study even pointed out a lower GRF value on the vertical axis for boots with blade-shaped studs compared with round-shaped studs. ${ }^{34}$ In view of the limitation of the variable observed and the results found, it is not possible to say that blade-shaped studs represent any indication of external mechanical overload in runs and landing. 
Table 2. Analysis of methodological quality of the studies included, according to the Downs and Black methodology.24

\begin{tabular}{|c|c|c|c|c|c|c|c|c|}
\hline Quality criteria items & Bentley et $\mathrm{al}^{32}$ & Bentley et $\mathrm{al}^{31}$ & DeBiaso et $\mathrm{al}^{33}$ & Gehring et $\mathrm{al}^{29}$ & Kaila et al ${ }^{30}$ & $\begin{array}{l}\text { MgGhie and } \\
\text { Ettema }^{34}\end{array}$ & Queen et $\mathrm{al}^{28}$ & Stefanyshyn et $\mathrm{al}^{27}$ \\
\hline 1. Clear objective & 1 & 1 & 1 & 1 & 1 & 1 & 1 & 1 \\
\hline $\begin{array}{l}\text { 2. Clear description } \\
\text { of key variables }\end{array}$ & 1 & 1 & 1 & 1 & 1 & 1 & 1 & 1 \\
\hline $\begin{array}{c}\text { 3. Clear description of } \\
\text { volunteers' characteristics }\end{array}$ & 1 & 1 & 1 & 1 & 1 & 1 & 1 & 1 \\
\hline $\begin{array}{l}\text { 4. Clear description } \\
\text { of the intervention }\end{array}$ & 1 & 1 & 1 & 1 & 1 & 1 & 1 & 1 \\
\hline $\begin{array}{l}\text { 6. Clear description } \\
\text { of key findings }\end{array}$ & 1 & 1 & 1 & 1 & 1 & 1 & 1 & 1 \\
\hline $\begin{array}{l}\text { 7. Description of random } \\
\text { variability estimates }\end{array}$ & 1 & 1 & 1 & 1 & 1 & 1 & 1 & 1 \\
\hline $\begin{array}{l}\text { 11. Selected volunteers } \\
\text { are representative of } \\
\text { the entire population }\end{array}$ & 0 & 0 & 0 & 0 & 0 & 0 & 0 & 0 \\
\hline $\begin{array}{l}\text { 16. Planned analysis } \\
\text { of subgroups }\end{array}$ & 1 & 1 & 1 & 1 & 1 & 1 & 1 & 1 \\
\hline $\begin{array}{c}\text { 18. Adequate } \\
\text { statistical analysis. }\end{array}$ & 1 & 1 & 1 & 1 & 1 & 1 & 1 & 1 \\
\hline $\begin{array}{c}\text { 20. Accurate } \\
\text { measurement of variables }\end{array}$ & 1 & 1 & 1 & 1 & 1 & 1 & 1 & 1 \\
\hline $\begin{array}{l}\text { 25. Adjustment for } \\
\text { confounding factors }\end{array}$ & 1 & 1 & 0 & 0 & 0 & 1 & 1 & 0 \\
\hline Finding (Up to 12) & 10 & 11 & 9 & 9 & 9 & 10 & 10 & 9 \\
\hline quality \% & 83 & 92 & 75 & 75 & 75 & 83 & 83 & 75 \\
\hline
\end{tabular}

Although the theme of this study is of interest to both researchers and sports professionals, only 8 studies have been found to present the state of the art. Although the selected studies present a high quality score according to the Downs and Black scale, ${ }_{1}^{24}$ it should be noted that longitudinal studies on the effects of blade-shaped studs on overload in less controlled situations in laboratory environments are still necessary for an applicability that is closer to the reality of the game and the athletes.

\section{CONCLUSION}

The findings of the articles included in this review indicate that the use of boots with blade-shaped studs does not result in greater mechanical overload on soccer players during runs with or without change of direction or in landing situations. To date, there is no evidence in the scientific literature that contraindicate wearing boots with blade-shaped studs to prevent injuries related to mechanical overload in soccer movements.

\section{ACKNOWLEDGEMENTS}

The authors acknowledge CNPq (Conselho Nacional de Desenvolvimento Científico e Tecnológico) for the scholarship granted to Cardoso Filho, CA. The fund providers had no influence on the decision to prepare and publish the article.

All authors declare no potential conflict of interest related to this article

AUTHORS' CONTRIBUTIONS: Each author made and significant individual contributions to this manuscript. CACF (0000-0003-3204-9397)*: writing the article, individual conception of the article, preparation of the entire research project, analysis and interpretation of the data for the work; JCG (0000-0002-0263-8118)*: substantial contribution to the design of the work, analysis and interpretation of the data for the work, critical review of the intellectual content; WPL (0000-0002-1832-5108)*: contribution to the design of the work and review of the article; ACA (0000-0002-2527-2163)*: critical review of the intellectual content and final approval of the version of the manuscript to be published; JCS (0000-0002-3646-3387)* substantial contribution to the conception of the work, critical review of the intellectual content and final approval of the version of the manuscript to be published. ${ }^{*}$ ORCID (Open Researcher and Contributor ID).

\section{REFERENCES}

1. Hennig EM, Sterzing T. The influence of soccer shoe design on playing performance: A series of biomechanical studies. Footwear Sci. 2010;2(1):3-11

2. FIFAC. FIFA Big Count 2006: 270 million people active in football. FIFA Commun Div Inf Serv. 2007;31:1-12.

3. Di Salvo V, Baron R, Tschan H, Calderon Montero FJ, Bachl N, Pigozzi F. Performance characteristics according to playing position in elite soccer. Int J Sports Med. 2007;28(3):222-7.

4. FIFA. Laws of the game 2017/18. Fédération Int Footb Assoc. 2017. [acesso em 27 nov 2017]:1-202. Disponível em: http://www.fifa.com/development/education-and-technical/referees/laws-of-the-game.html.

5. Hilgers MP, Walther M. Evolution of Soccer Shoe Design. Mokha M, ed. Int J AthlTher Train. 2011;16(3):1-4.

6. Sterzing T, Müller C, Hennig EM, Milani TL. Actual and perceived running performance in soccer shoes: A series of eight studies. Footwear Sci. 2009;1(1):5-17.

7. Sterzing T, Hennig EM. The Influence of Soccer Shoes on Kicking Velocity in Full-Instep Kicks. Exerc Sport Sci Rev. 2008;36(2):91-7.

8. Kirk RF, Noble ISG, Mitchell T, RolfC, Haake SJ, Carré MJ. High-speed observations of football-boot-surface interactions of players in their natural environment. Sport Eng. 2007;10(3):129-44.

9. Kulessa DJ, Gollhofer A, Gehring D. The influence of football shoe characteristics on athletic performance and injury risk-a review. Footwear Sci. 2017;9(1):49-63.

10. Hall MJ, Riou P. Football blades: a cause for concern. Br J Sports Med. 2004;38(5):642.

11. O'Connor A-M, James IT. Association of lower limb injury with boot cleat design and playing surface in elite soccer. Foot Ankle Clin. 2013;18(2):369-80.

12. Smeets $\mathrm{K}$, Jacobs $\mathrm{P}$, Hertogs $\mathrm{R}$, et al. Torsional injuries of the lower limb: an analysis of the frictional torque between different types of football turf and the shoe outsole. Br J Sports Med. 2012;46(15):1078-83.

13. Sterzing T, Müller C, Wächtler T, Milani TL. Shoe influence on actual and perceived ball handling performance in soccer. Footwear Sci. 2011;3(2):97-105.

14. Alentorn-Geli E, Myer GD, Silvers HJ, et al. Prevention of non-contact anterior cruciate ligament injuries in soccer players. Part 1: Mechanisms of injury and underlying risk factors. Knee Surgery, Sport Traumatol Arthrosc. 2009;17(7):705-29. 
15. Waldén M, Hägglund M, Magnusson H, Ekstrand J. Anterior cruciate ligament injury in elite football: A prospective three-cohort study. Knee Surgery, Sport Traumatol Arthrosc. 2011;19(1):11-9.

16. Lambson RB, Barnhill BS, Higgins RW. Football cleat design and its effect on anterior cruciate ligament injuries. A three-year prospective study. Am J Sports Med. 1996;24(2):155-9.

17. Ryder SH, Johnson RJ, Beynnon BD, Ettlinger CF. Prevention of ACL injuries. J Sport Rehabil. 1997;6(2):80-96.

18. Hennig EMEM. Plantar pressure measurements for the evaluation of shoe comfort, overuse injuries and performance in soccer. Footwear Sci. 2014;6(2):119-27.

19. Sims ELL, Hardaker WMM, Queen RMM. Gender differences in plantar loading during three soccer-specific tasks. Br J Sports Med. 2008;42(4):272-7.

20. Ekstrand J, Hägglund M, Waldén M. Injury incidence and injury patterns in professional football: the UEFA injury study. Br J Sports Med. 2011;45(7):553-8.

21. Hennig EM. The influence of soccer shoe design on player performance and injuries. Res Sport Med. 2011:19(3):186-201.

22. Whiting W, Zernicke R. Mechanisms of musculoskeletal injury. In: Biomechanics in Sport. 2nd Editio. Blackwell Science Ltd. 2008:507-22.

23. Moher D, Liberati A, Tetzlaff J, Altman DG; PRISMA Group. Preferred reporting items for systematic reviews and meta-analyses: The PRISMA statement. PLoS Med. 2009;6(7):e1000097.

24. Downs SH, Black N. The feasibility of creating a checklist for the assessment of the methodological quality both of randomised and non-randomised studies of health care interventions. J Epidemiol Community Health. 1998;52(6):377-84

25. van der Worp H, Vrielink JW, Bredeweg SW. Do runners who suffer injuries have higher vertical ground reaction forces than those who remain injury-free? A systematic review and meta-analysis. Br J Sports Med. 2016;50(8):450-7.

26. Munteanu SE, Barton CJ. Lower limb biomechanics during running in individuals with achilles tendinopathy: a systematic review. J Foot Ankle Res. 2011;4:15.

27. Stefanyshyn DJ, Lee JS, Park SK. The influence of soccer cleat design on resultant joint moments. Footwear Sci. 2010;2(1):13-9

28. Queen RMM, Charnock BLL, Garrett WE Jr, Hardaker WM, Sims EL, Moorman CT 3rd. A comparison of cleat types during two football-specific tasks on FieldTurf. Br J Sports Med. 2008:42(4):278-84

29. Gehring D, Rott F, Stapelfeldt B, Gollhofer A. Effect of soccer shoe cleats on knee joint loads. Int J Sports Med. 2007;28(12):1030-4

30. Kaila R. Influence of modern studded and bladed soccer boots and sidestep cutting on knee loading during match play conditions. Am J Sports Med. 2007;35(9):1528-36
31. Butler RJ, Russell ME, Queen R. Effect of soccer footwear on landing mechanics. Scand J Med Sc Sports. 2014;24(1):129-35.

32. Bentley JA, Ramanathan AK, Arnold GP, Wang W, Abboud RJ. Harmful cleats of football boots: a biomechanical evaluation. Foot Ankle Surg. 2011;17(3):140-4.

33. Debiasio JC, Russell ME, Butler RJ, Nunley JA, Queen RM. Changes in Plantar Loading Based on Shoe Type and Sex During a Jump-Landing Task. J Athl Train. 2013;48(5):601-9.

34. McGhie D, Ettema G. Biomechanical analysis of surface-athlete impacts on third-generation artificial turf. Am J Sports Med. 2013;41(1):177-85.

35. NovacheckTF. Review paper: The biomechanics of running. Gait Posture. 1998;7(1):77-95.

36. Nigg BM, Segesser B. Biomechanical and orthopedic concepts in sport shoe construction. Med Sc Sports Exerc. 1992;24(5):595-602

37. Bahr R, Clarsen B, Ekstrand J. Why we should focus on the burden of injuries and illnesses, not just their incidence. Br J Sports Med. 2018:(52(16):1018-21.

38. Hewett TE, Myer GD, Ford KR, Heidt RS Jr, Colosimo AJ, McLean SG, et al. Biomechanical measures of neuromuscular control and valqus loading of the knee predict anterior cruciate ligament injury risk in female athletes: a prospective study. Am J Sports Med. 2005;33(4):492-501.

39. Shimokochi Y, Shultz SJ. Mechanisms of noncontact anterior cruciate ligament injury. J Athl Train. 2008;43(4):396-408

40. Yu B, Garrett WE. Mechanisms of non-contact ACL injuries. Br J Sports Med. 2007:41(Suppl 1):i47-51.

41. Lambson RB, Barnhill BS, Higgins RW. Football cleat design and its effect on anterior cruciate ligament injuries: A three-year prospective study. Am J Sports Med. 1996;24(2):155-9.

42. Ekstrand J, van Dijk CN. Fifth metatarsal fractures among male professional footballers: a potential career-ending disease. Br J Sports Med. 2013;47(12):754-8.

43. Dhillon MS, Ekstrand J, Mann G, Sharma S. Stress fractures in football. J ISAKOS Jt Disord Orthop Sport Med. 2016;1(4):229-38

44. Carl HD, Pauser J, Swoboda B, Jendrissek A, Brem M. Soccer boots elevate plantar pressures in elite male soccer professionals. Clin J Sport Med. 2014;24(1):58-61

45. Azevedo RR, da Rocha ES, Franco PS, Carpes FP. Plantar pressure asymmetry and risk of stress injuries in the foot of young soccer players. Phys Ther Sport. 2017;24(1):39-43.

46. Nigg BM, Baltich J, Hoerzer S, Enders H. Running shoes and running injuries: mythbusting and proposal for two new paradigms: "preferred movement path" and "comfort filter." Br J Sports Med. 2015;49(20):1290-4.

47. Zadpoor AA, Nikooyan AA. The relationship between lower-extremity stress fractures and the ground reaction force: A systematic review. Clin Biomech. 2011:26(1):23-8. 